\title{
MECHANICAL PROPERTIES BETON AGROPOLIMER ABU SEKAM PADI DENGAN AKTIVATOR SODIUM SILIKAT DAN SODIUM HIDROKSIDA
}

\author{
Cut Yusnar ${ }^{1)}$, Ruhana $^{2)}$, Sulaiman $\mathbf{Y H}^{3)}$ \\ ${ }^{122) 3)}$ Jurusan Teknik Sipil, Politeknik Negeri Lhokseumawe \\ Jl. Banda Aceh-Medan Km. 280, P.O. Box 90, Buketrata, Lhokseumawe 24301 \\ e-mail: cut_yusnar@yahoo.com
}

\begin{abstract}
Abstrak
Abu sekam padi umum digunakan sebagai material tambahan yang telah digunakan untuk beton geopolimer. Tulisan ini melaporkan perilaku mekanis (tekan dan lentur) dari beton geopolimer abu sekam padi yang menggunakan aktivator sodium silikat dan sodium hidroksida dengan perbandingan sodium silikat terhadap sodium hidroksida 0,$25 ; 0,1$; dan 1,25 . Pengujian beton bertujuan mendapatkan sifat kuat tekan dan lentur. Hasil pengujian menunjukkan bahwa kuat tekan beton optimum terjadi pada beton dengan perbandingan sodium silikat terhadap sodium hidroksida 1,0 dan kuat lentur beton mencapai optimum pada perbandingan sodium silikat terhadap sodium hidroksida 1,25 .
\end{abstract}

Kata kunci: beton geopolimer, kuat tekan, kuat lentur, aktivator

\begin{abstract}
Rice Husk Ash usually used as pozzolanic material admixtures that have been used for Geopolimer concrete. This study report on the behavior on mechanical properties (compressive and flexural) of rice husk ash geopolimer concrete using activator sodium silicate and sodium hydroxide with variation comparison of sodium silicate to sodium hydroxide was 0,25; 0,1; and 1,25. Concrete testing included the determination of compressive and flexural properties. It was shown that the behavior of compressive properties of comparison of sodium silicate to sodium hydroxide 1,0 was the optimum result and the behavior of flexure properties got optimum result on the comparison of sodium silicate and sodium hydroxide was 1,25.
\end{abstract}

Keywords: geopolimer concrete, compressive strength, flexural strength, activator 


\section{PENDAHULUAN}

Pemanfaatan bahan limbah baik yang bersumber dari limbah industri seperti pemanfaatan abu terbang (fly ash) sisa dari industri batu bara maupun dari limbah pertanian yang banyak mengandung silikat seperti abu ampas tebu, abu sekam padi maupun bahan organik lainnya. Pemanfaatan abu sekam padi baik sebagai bahan pengganti semen secara parsial maupun menggantikan semen secara menyeluruh diawali oleh penilitian David Dovit (1976) yang mengacu pada rantai 3D polisialat yang dihasilkan dari hidroksilasi dan polikondensasi pada tempratur di bawah $160 \mathrm{C}^{0}$ dari mineral alam seperti kaolin dan abu terbang.

Beton agropolimer adalah beton polimer berbahan dasar dari limbah pertanian (agro) seperti abu sekam padi dan abu ampas tebu. Beton polimer adalah beton dengan menggunakan bahan mineral alumino silikat $\left(\mathrm{SiO}_{2}\right.$ dan $\left.\mathrm{Al}_{2} \mathrm{O}_{3}\right)$ untuk menggantikan rantai C. Beton polimer disebut juga beton geopolimer. Istilah geopolimer diperkenalkan oleh Daviddovits pada tahun 1976 yang mengacu pada rantai 3D polisialat yang dihasilkan dari hidroksilasi dan polikondensasi pada tempratur di bawah $160 \mathrm{C}^{0}$ dari mineral alam seperti kaolin dan abu terbang.

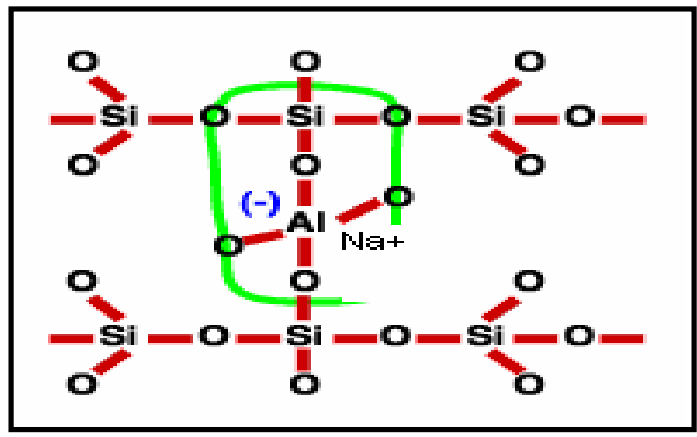

Gambar 1. Ikatan yang terjadi dalam geopolimer (Daviddovits, 2008)

Beton geopolimer berbeda dengan beton portland baik dari sifat-sifat fisik maupun sifat-sifat kimia. Adapun perbedaan tersebut adalah dalam hal:

a) Proses pengerasan

Semen yang dicampur air akan terhidrolisa menjadi kalsium hidroksida $(\mathrm{CaOH})_{2}$ dan kalsium silikat hidrat $\left(3 \mathrm{CaO} .2 \mathrm{SiO}_{2} .3 \mathrm{H}_{2} \mathrm{O}\right)$ yang terjadi pada suhu ruang.

$2(3 \mathrm{CaO} .2 \mathrm{SiO} 2)+6 \mathrm{H} 2 \mathrm{O} \rightarrow$ $(3 \mathrm{CaO} .2 \mathrm{SiO} 2.3 \mathrm{H} 2 \mathrm{O})+3 \mathrm{Ca}(\mathrm{OH}) 2$

Adapun pengerasan pada beton geopolimer adalah proses pengerasan yang disebabkan oleh reaksi polikondensasi material alumino silikat $\left(\mathrm{SiO}_{2}\right.$ dan $\left.\mathrm{Al}_{2} \mathrm{O}_{3}\right)$.

b) Penyusutan (creep)

Penyusutan pada beton geopolimer mempunyai nilai creep yang rendah dibandingkan dengan beton portland. Beton geopolimer mampu mencapai 70 $\%$ kekuatannya pada 4 jam pertama (Khale dan Chaundhary, 2007), sedangkan untuk nilai Modulus Young, Poisson's ratio, dan tensile strength relatif sama.

c) Derajat keasaman $(\mathrm{pH})$

Derajat keasaman $(\mathrm{pH})$ beton geopolimer berkisar antara 11,5 - 12,5, sedangkan $\mathrm{pH}$ beton portland berkisar antara $12-13$. Derajat keasaman yang relatif sama dengan beton semen portland memungkinkan beton geopolimer aman dan tidak merusak baja tulangan (Davidovit, 2008).

d) Karbonisasi di sekeliling baja

Semen portland memiliki ion hidroksil bebas yang mengalami karbonasi dari $(\mathrm{CaOH})_{2}$ menjadi $\mathrm{CaCO}_{3}$. Karbonasi semen portland dapat menghilangkan ion hidroksil dan menurunkan $\mathrm{pH}$. Hal ini dapat mengakibatkan korosi di sekeliling baja. Adapaun karbonasi pada beton geopolimer menghasilkan kalium karbonat atau natrium karbonat dengan pH 10 -10,5 (Davidovits, 2008). Hal ini sebaliknya dapat melindungi tulangan dari resiko korosi. 
Kandungan alkali pada beton polimer, tidak menyebabkan reaksi alkali agregat, sedangkan alkalin pada beton semen portland dapat menyebabkan reaksi alkali-aregat yang merusak. Reaksi alkali-agregat adalah serangkaian kimia yang melibatkan alkali hidroksida dari semen dengan silikat reaktif yang ada pada agregat. Pada tahapan .ini membutuhkan air dalam pembentukan gel alkali-silikat, jika berada dalam kondisi lembab maka akan mengembang sehingga menimbulkan swelling pressure yang menyebabkan kerusakan pada beton berupa retak sampai terkelupas. Sedangkan pada beton geopolimer kandungan alkali tidak menyebabkan reaksi alkali agregat (Davidivits, 2008).

e) Reaksi alkali yang terjadi pada beton polimer, proses reaksi terjadi empat tahapan yaitu; (1) Reaksi disolusi permukaan $\mathrm{Al}$ dan $\mathrm{Si}$ dalam larutan alkali. (2) Terjadi diffuse material yang terlarut. (3) terjadi polikondensasi senyawa $\mathrm{Al}$ dan $\mathrm{Si}$ dengan adanya larutan silikat dan membentuk gel, serta (4) terjadi proses pengerasan gel sebagai akibat produk finalisasi.

f) Ion klorida tidak mempengaruhi korosi pada beton. Ion klorida dapat menyebabkan korosi dan pengeroposan pada beton semen portland karena ion klorida dapat menyerang sistem pengikat kalsium silikat hidrat. Oleh karena itu dalam pelaksanaan beton semen portland tidak dibenarkan menggunakan air yang mengandung klorida. Adapun beton geopolimer memiliki ketahanan terhadap ion klorida (Davidovits, 2008).

Material aktivasi alkali (Alkali activated material) adalah material yang dibentuk dengan melakukan aktivasi alkali (menggunakan aktivator alkali) terhadap material dasar yang kaya silikat-alumina (sebagai precursor). Aktivator alkali yang biasa digunakan adalah senyawa sodium ataupun senyawa potassium.

Sementara material yang disebut kaya silikat alumina dihasilkan oleh dua sumber yaitu: yang berasal dari alam (Origin source) seperti abu gunung, clay, kaolin, dan metakaolin. Sedangkan yang berasal dari hasil sampingan produksi (by produk) seperti fly ash, slugh, silica fume, abu sekam padi (rice husk ash), red mud, dan sebagainya.

Aktivator alkali yang digunakan adalah campuran larutan Sodium Hidroksida $(\mathrm{NaOH})$ dengan laruan natrium silikat $\left(\mathrm{Na}_{2} \mathrm{SiO}_{3}\right)$. Larutan $\mathrm{NaOH}$ diperoleh dengan mencampurkan $\mathrm{NaOH}$ solid dengan sejumlah aquades, dan untuk larutan $\mathrm{Na}_{2} \mathrm{SiO}_{3}$ yang digunakan adalah dengan komposisi $\mathrm{SiO}_{2}$ sebanyak 37,23\% dan $\mathrm{Na}_{2} \mathrm{O}$ sebanyak $15,98 \%$ dengan spesifik gravity $1,65 \mathrm{gr} / \mathrm{cm}^{3}$.

Abu sekam padi (rice husk ash) yang diperoleh dari limbah pabrik penggilingan padi, selanjutnya dibakar dengan menggunakan drum sebagai tahap awal untuk menghilangkan unsur karbon. Proses pembakaran kedua dilakukan dengan furnace untuk suhu pembakaran $700 \mathrm{C}^{0}$ (Ismail dan Waliuddin, 1996).

Partikel silikat hasil pembakaran yang berbentuk amorphous setelah proses pembakaran akan menghasilkan silicon murni, karbid silicon, dan tepung nitrid silicon (Katsuki et al, 2005). Selanjutnya setelah selesai proses pembakaran dilanjutkan dengan penghalusan dengan menggunakan mesin Los Angelos guna mendapatkan ukuran partikel yang lebih kecil kristabolik (R. Zerbino, 2012), sehingga proses reaksi alkali-silikat dalam mortal beton lebih baik.

Pengembangan lebih lanjut terhadap beton geopolimer terus berkembang. Dari tahapan substitusi sebagian dari semen dengan materal yang bersifat sementitous sampai 
kepada tidak menggunakan semen sama sekali, akan tetapi digantikan dengan material aktivator yang mengaktifkan material silikat dan alumina sehingga berfungsi sebagai larutan pengikat. Penelitian lebih lanjut mengenai beton geopolimer diantaranya oleh C.Y.Heah, dkk (2012) hasil penelitiannya membuktikan adanya pengaruh rasio perbandingan aktivator Sodium Silikat terhadap Sodium Hidroksida terhadap kekuatan beton geopolimer serta adanya pengaruh tingkat konsentrasi larutan (molar) terhadap sifat reaktiviti beton geopolimer.

Selanjutnya Yun Yong Kim, dkk (2014) Strength and Durability Performance Alcali Activated Rice Husk Ash Geopolimer Mortal meneliti tentang karakter durability mortal beton geopolimer dengan perlakuan terhadap variasi metode perawatan beton serta variasi konsentrasi Molar activator. Hasil penelitianya memperlihatkan bahwa mortar beton geopolimer dengan menggunakan abu sekam padi mempunyai potensi yang besar untuk menggantikan semen portland.

\section{METODE PENELITAN}

\section{Material}

Tahapan penelitian yang telah dilaksanakan di laboratorium Bahan Teknik Sipil Politeknik Negeri Lhokseumawe dilaksanakan dalam 3 tahap sebagai berikut:

a) Tahap I berupa persiapan material geopolimer yaitu pengambilan material abu sekam padi yang sudah di bakar dari pabrik penggilingan padi yang berada di desa Bayu. Selanjutnya material ini dijemur sampai kering baru dihaluskan dengan menggunakan mesin Los Angeles dan diayak dengan saringan 200.

b) Selanjutnya material abu sekam padi yang telah lolos saringan 200 ini, sebelum digunakan sebagai campuran binder maupun sebagai campuran beton geopolimer terlebih dahulu diperiksa kadar silikat (Si) dan Alkalin (Al) dengan peralatan SEM (Scanning Electron Microscopy). Dari hasil pemeriksaan diperoleh kadar Silikat (Si) yang digunakan pada penelitian ini adalah $90,79 \%$ dalam bentuk senyawa $\mathrm{SiO}_{2}$ dan kadar Alkalin sebesar 2,22\% dalam bentuk senyawa $\mathrm{Al}_{2} \mathrm{O}_{3}$. Selanjutnya material abu sekam padi yang telah dihaluskan siap digunakan sesuai dengan porsinya masing-masing.

c) Sementara mempersiapkan material abu sekam padi, dilakukan penyelidikan sifat-sifat fisik agregat batu pecah dan pasir.

d) Tahap II dari penelitian ini adalah membuat benda uji (sampel) binder geopolimer sesuai dengan rancangan campuran beton geopolimernya yaitu:

a. Untuk binder beton geopolimer dengan perbandingan aktivator 0,25

b. Untuk binder beton geopolimer dengan perbandingan aktivator 1

c. Untuk binder beton geopolimer dengan perbandingan aktivator 1,25.

Material activator adalah Larutan water glass (Sodium Silicate $\mathrm{Na}_{2} \mathrm{SiO}_{3}$ ) dan Sodium Hidroksida $(\mathrm{NaOH})$. Senyawa Sodium Hidroksida dalam bentuk padat (solid), selanjutnya dilarutkan dengan cairan aquades dengan konsentrasi larutan larutan Water Glass. Larutan aktivator yang telah ditimbang sesuai perbandingan $\mathrm{Na}_{2} \mathrm{SiO}_{3}$ $\mathrm{NaOH}=0,25 ; \mathrm{Na}_{2} \mathrm{SiO}_{3}: \mathrm{NaOH}=1,0$ dan $\mathrm{Na}_{2} \mathrm{SiO}_{3}: \mathrm{NaOH}=1,25$

Kedua larautan aktivator dicampurkan dan diaduk sehingga tercampur merata. Larutan aktivator yang telah tercampur merata ini disebut "precursor". Untuk menetukan jumlah air yang dibutuhkan dapat dihitung dengan rumus sebagai berikut: Jumlah air : precursor $=0,3 \quad$ Setelah pencampuran larutan precursor dengan sejumlah air yang telah dihitung baru ditambahkan material agregat. 
Penggunaan agregat halus dan kasar digunakan sama dengan material agregat halus untuk beton normal dan jumlah agregat kasar yang digunakan sama dengan jumlah agregat kasar yang digunakan untuk beton normal dengan faktor air semen (fas) 0,3 , fas 0,35 dan fas 0,4 .

\section{Tahapan pelaksanaan}

a) Setelah material disediakan, kegiatan selanjutnya adalah membuat benda uji (sampel) sesuai dengan tujuan pengujian yang akan dilaksanakan. Benda uji dibuat untuk binder geopolimer menggunakan cetakan kubus ukuran $5 \mathrm{x}$ $5 \times 5 \mathrm{~cm}$ dan benda uji untuk beton geopolimer menggunakan cetakan silinder berdiameter $10 \mathrm{~cm}$ dan tinggi $20 \mathrm{~cm}$. Pada penelitian ini telah dibuat 30 buah silinder berdiameter $10 \mathrm{~cm}$ dan tinggi $20 \mathrm{~cm}$ dan 30 buah binder geopolimer yang berbentuk kubus berukuran $5 \mathrm{~cm} \times 5 \mathrm{~cm} \times 5 \mathrm{~cm}$.

b) Perawatan benda uji untuk beton geopolimer dilakukan dengan mengovenkan benda uji selama 24 jam pada temperatur $60 \mathrm{C}^{0}$ dan selanjutnya dibiarkan di udara terbuka pada suhu kamar sampai umur 21 hari.

c) Tahap III Pengujian benda uji yang meliputi pengujian:

a. Pengujian kuat tekan binder geopolimer pada umur 7 hari, digunakan benda uji kubus $5 \mathrm{~cm}$ x 5 $\mathrm{cm} \times 5 \mathrm{~cm}$.

b. Penguian kuat tekan beton geopolimer pada umur 21 hari, digunakan benda uji silinder diameter $10 \mathrm{~cm}$ dan tinggi $20 \mathrm{~cm}$.

c. Pengujian kuat tarik beton geopolimer pada umur 21 hari, digunakan benda uji silinder diameter $10 \mathrm{~cm}$ dan tinggi $20 \mathrm{~cm}$.
Untuk lebih jelasnya Gambar 2 memperlihatkan bagan alir penelitian ini.

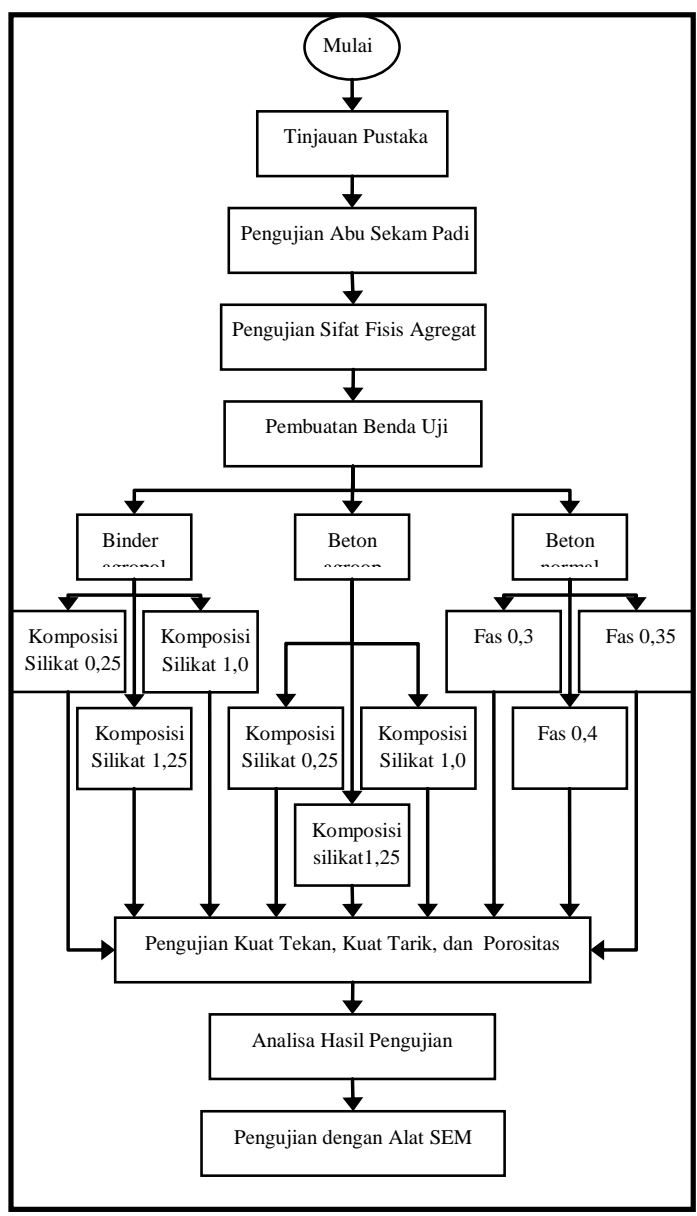

Gambar 2. Bagan Alir Penelitian

\section{HASIL DAN PEMBAHASAN}

Hasil penelitian diperoleh berupa data mekanikal properti dari beton geopolimer berbahan abu sekam padi yang diuji terhadap beban tekan dan beban tarik pada benda uji kubus $5 \mathrm{~cm} \times 5 \mathrm{~cm} \times 5 \mathrm{~cm}$ dan benda uji silinder diameter $10 \mathrm{~cm}$ dan tinggi $20 \mathrm{~cm}$. Berikut disajikan data kuat tekan dari benda uji kubus mortar geopolimer pada umur 7 hari dan silinder diameter $10 \mathrm{~cm}$ dan tinggi $20 \mathrm{~cm}$ pada umur 21 hari. 
Tabel 1. Hasil Kuat tekan benda uji kubus binder geopolimer $5 \mathrm{~cm} \mathrm{x} 5 \mathrm{~cm} \times$ $5 \mathrm{~cm}$

\begin{tabular}{|c|c|c|c|c|c|c|c|c|}
\hline No & \begin{tabular}{|c|} 
Alkali \\
Activator \\
$\mathrm{Na}^{2} \mathrm{SiO}^{3}$ \\
$/ \mathrm{NaOH}$
\end{tabular} & $\begin{array}{l}\text { Kode } \\
\text { B.Uji }\end{array}$ & $\begin{array}{l}\text { Umur } \\
\text { (Hari) }\end{array}$ & $\begin{array}{l}\text { Berat } \\
\text { (gr) }\end{array}$ & $\begin{array}{c}\text { Beban } \\
\mathrm{P} \\
(\mathrm{kN})\end{array}$ & $\begin{array}{c}\text { Luas } \\
\mathrm{A} \\
\left(\mathrm{mm}^{2}\right)\end{array}$ & $\mid \begin{array}{c}\sigma \\
21 \mathrm{Hari} \\
(\mathrm{MPa})\end{array}$ & $\begin{array}{c}\text { Rata-rata } \\
\sigma 21 \text { hari } \\
\text { (MPa) }\end{array}$ \\
\hline (1) & (2) & (3) & (4) & (5) & (6) & (7) & (8) & (9) \\
\hline \multirow{10}{*}{ I } & \multirow{10}{*}{0,25} & KI1 & 21 & 127 & 7185 & 2500 & 2,87 & \multirow{10}{*}{2,86} \\
\hline & & KI2 & 21 & 130 & 7245 & 2500 & 2,90 & \\
\hline & & KI3 & 21 & 126 & 6950 & 2500 & 2,78 & \\
\hline & & KI4 & 21 & 129 & 7200 & 2500 & 2,89 & \\
\hline & & KI5 & 21 & 130 & 7215 & 2500 & 2,89 & \\
\hline & & KI6 & 21 & 125 & 7210 & 2500 & 2,88 & \\
\hline & & KI7 & 21 & 135 & 6990 & 2500 & 2,79 & \\
\hline & & KI8 & 21 & 130 & 7100 & 2500 & 2,84 & \\
\hline & & KI9 & 21 & 128 & 7200 & 2500 & 2,88 & \\
\hline & & KI10 & 21 & 130 & 7200 & 2500 & 2,88 & \\
\hline \multirow{10}{*}{ II } & \multirow{10}{*}{1,0} & KII1 & 21 & 123 & 9800 & 2500 & 3,92 & \multirow{10}{*}{3,89} \\
\hline & & KII2 & 21 & 133 & 9873 & 2500 & 3,95 & \\
\hline & & KII3 & 21 & 130 & 9900 & 2500 & 3,96 & \\
\hline & & KII4 & 21 & 127 & 9870 & 2500 & 3,95 & \\
\hline & & KII5 & 21 & 137 & 9760 & 2500 & 3,90 & \\
\hline & & KII6 & 21 & 132 & 9830 & 2500 & 3,93 & \\
\hline & & KII7 & 21 & 135 & 9750 & 2500 & 3,90 & \\
\hline & & KII8 & 21 & 129 & 9770 & 2500 & 3,91 & \\
\hline & & KII9 & 21 & 127 & 8970 & 2500 & 3,59 & \\
\hline & & KIII0 & 21 & 122 & 9743 & 2500 & 3,89 & \\
\hline \multirow{10}{*}{ III } & \multirow{10}{*}{1,25} & KIII1 & 21 & 129 & 6240 & 2500 & 2,49 & \multirow{10}{*}{2,58} \\
\hline & & KIII2 & 21 & 129 & 6560 & 2500 & 2,62 & \\
\hline & & KIII3 & 21 & 130 & 6449 & 2500 & 2,58 & \\
\hline & & KIII4 & 21 & 127 & 6470 & 2500 & 2,59 & \\
\hline & & KIII5 & 21 & 130 & 6397 & 2500 & 2,56 & \\
\hline & & KIII6 & 21 & 128 & 6276 & 2500 & 2,51 & \\
\hline & & KIII7 & 21 & 131 & 6490 & 2500 & 2,60 & \\
\hline & & KIII8 & 21 & 129 & 6530 & 2500 & 2,61 & \\
\hline & & KIII9 & 21 & 132 & 6760 & 2500 & 2,70 & \\
\hline & & KIIIIO & 21 & 130 & 6290 & 2500 & 2,52 & \\
\hline
\end{tabular}

Dari data pengujian kuat tekan kubus mortal beton geopolimer pada umur 21 hari terlihat hasil kuat tekan optimum diperoleh dari kelompok benda uji dengan perbandingan aktivator sodium silikat terhadap sodium hidroksida sama dengan satu yaitu kuat tekan rata-rata dari benda uji silinder berdiameter $10 \mathrm{~cm}$ dan tinggi $20 \mathrm{~cm}$ sebesar 0,039 MPa.

Pada penggunaan aktivator natrium silikat yang lebih kecil maupun lebih besar dari natrium hidroksida dari hasil kuat tekan terlihat tidak mempengaruhi terhadap peningkatan nilai kuat tekan beton geopolimer. Hal yang sama juga diperlihatkan oleh hasil penelitian Yun Yong Kim, dkk (2014). Tabel 2 memperlihatkan data hasil pengujian terhadap kuat tekan pada 15 benda uji silinder diameter $10 \mathrm{~cm}$ dan tinggi $20 \mathrm{~cm}$.

Tabel 2. Hasil Kuat Tekan Beton Geopolimer dengan Benda Uji Silinder Diameter $10 \mathrm{~cm}$ dan Tinggi $20 \mathrm{~cm}$

\begin{tabular}{|c|c|c|c|c|c|c|c|c|}
\hline No & \begin{tabular}{|l} 
Alkali \\
Activator \\
$\mathrm{Na}^{2} \mathrm{SiO}^{3}$ \\
$/ \mathrm{NaOH}$
\end{tabular} & $\begin{array}{l}\text { Kode } \\
\text { B.Uji }\end{array}$ & $\begin{array}{l}\text { Umur } \\
\text { (Hari) }\end{array}$ & $\begin{array}{c}\text { Berat } \\
\text { (gr) }\end{array}$ & $\begin{array}{c}\text { Beban } \\
\mathrm{P} \\
(\mathrm{kN})\end{array}$ & $\begin{array}{c}\text { Luas } \\
\text { A } \\
\left(\mathrm{mm}^{2}\right)\end{array}$ & $\begin{array}{c}\sigma \\
21 \stackrel{\text { Hari }}{\text { (MPa) }}\end{array}$ & $\begin{array}{l}\text { Rata-rata } \\
\sigma 21 \text { hari } \\
\text { (MPa) }\end{array}$ \\
\hline (1) & (2) & (3) & (4) & (5) & (6) & (7) & (8) & (9) \\
\hline \multirow{5}{*}{ I } & \multirow{5}{*}{0,25} & ST11 & 21 & 2470 & 81,02 & 7850 & 10,32 & \multirow{5}{*}{10,22} \\
\hline & & $\overline{\text { ST12 }}$ & 21 & 2475 & 79,50 & 7850 & 10,13 & \\
\hline & & ST13 & 21 & 7470 & 80,75 & 7850 & 10,29 & \\
\hline & & ST14 & 21 & 2480 & 79,55 & \begin{tabular}{|l|l|}
7850 \\
\end{tabular} & 10,18 & \\
\hline & & ST15 & 21 & 2476 & 79,90 & 7850 & 10,19 & \\
\hline \multirow{5}{*}{ II } & \multirow{5}{*}{1,0} & ST21 & Rt5 & 2780 & 122,4 & 7850 & 15,59 & \multirow{5}{*}{15,34} \\
\hline & & ST22 & 21 & 2785 & 121,7 & 7850 & 15,50 & \\
\hline & & ST23 & 21 & 2776 & 120,9 & 7850 & 15,40 & \\
\hline & & ST24 & 21 & 2770 & 118,5 & 7850 & 15,09 & \\
\hline & & ST25 & 21 & 2840 & 120,2 & 7850 & 15,31 & \\
\hline \multirow{5}{*}{ III } & \multirow{5}{*}{1,25} & ST31 & 21 & 2810 & 80,95 & 7850 & 10,31 & \multirow{5}{*}{10,33} \\
\hline & & ST32 & 21 & 2840 & 79,80 & 7850 & 10,17 & \\
\hline & & ST33 & 21 & 2980 & 82,30 & 7850 & 10,49 & \\
\hline & & ST34 & 21 & 2865 & 81,50 & 7850 & 10,38 & \\
\hline & & ST35 & 21 & 2870 & 80.75 & 7850 & 10,29 & \\
\hline
\end{tabular}

Data hasil pengujian pada Tabel 2 memperlihatkan hasil kuat tekan optimum yang diperoleh dari pengujian terhadap 15 belas benda uji silinder pada tiga katagori aktivator. Data hasil kuat tekan memperlihatkan kekuatan tekan optimum dihasilkan pada aktivator dengan perbandingan Sodium silikat terhadap sodium hidroksida adalah satu. Nilai kuat tekan rata-rata diperoleh sebesar 15,34 MPa. Hal ini menunjukkan bahwa peran aktivator pada beton geopolimer menentukan kekuatan tekan yang diperoleh. Berbeda halnya dengan beton Portland Cement (PC) dimana kekuatan beton dipengaruhi oleh perbandingan antara jumlah air terhadap jumlah semen (fas).

Untuk pengujian kuat tarik beton geopolimer berbentuk silinder diameter $10 \mathrm{~cm}$ dan tinggi $20 \mathrm{~cm}$ disajikan pada tabel 3 berikut ini: 
Tabel 3. Hasil Kuat Tarik Beton Geopolimer dengan Benda Uji Silinder Diameter $10 \mathrm{~cm}$ dan Tinggi $20 \mathrm{~cm}$

\begin{tabular}{|c|c|c|c|c|c|c|c|c|}
\hline No & $\begin{array}{c}\text { Alkali } \\
\text { Activator } \\
\mathrm{Na}^{2} \mathrm{SiO}^{3} \\
/ \mathrm{NaOH}\end{array}$ & $\begin{array}{l}\text { Kode } \\
\text { B.Uji }\end{array}$ & $\begin{array}{l}\text { Umur } \\
\text { (Hari) }\end{array}$ & $\begin{array}{c}\text { Berat } \\
\text { (gr) }\end{array}$ & $\begin{array}{c}\text { Beban } \\
\mathrm{P} \\
(\mathrm{kN})\end{array}$ & $\begin{array}{l}\text { Luas } \\
\text { A }\left(\mathrm{mm}^{2}\right) \\
(\pi . \mathrm{L} . \mathrm{D})\end{array}$ & $\begin{array}{c}\sigma \\
21 \\
\text { Hari } \\
\text { (MPa) }\end{array}$ & $\begin{array}{l}\text { Rata-rata } \\
\sigma 21 \text { hari } \\
\text { (MPa) }\end{array}$ \\
\hline (1) & (2) & (3) & (4) & (5) & (6) & (7) & (8) & (9) \\
\hline \multirow{5}{*}{ I } & \multirow{5}{*}{0,25} & SA11 & 21 & 2479 & 96,4 & 62800 & 3,07 & \multirow{5}{*}{3,01} \\
\hline & & SA12 & 21 & 2467 & 90,6 & 62800 & 2,89 & \\
\hline & & \begin{tabular}{|l|l|} 
SA13 \\
\end{tabular} & 21 & 2490 & 92,3 & 62800 & 2,94 & \\
\hline & & SA14 & 21 & 2475 & 95,7 & 62800 & 3,05 & \\
\hline & & SA15 & 21 & 2456 & 97,2 & 62800 & 3,1 & \\
\hline \multirow{5}{*}{ II } & \multirow{5}{*}{1,0} & SA21 & 21 & 2790 & 97,2 & 62800 & 3,1 & \multirow{5}{*}{3,07} \\
\hline & & SA22 & 21 & 2795 & 94,5 , & 62800 & 3,0 & \\
\hline & & \begin{tabular}{|l|l|} 
SAA3 \\
\end{tabular} & 21 & 2785 & 97,3 & 62800 & 3,09 & \\
\hline & & \begin{tabular}{|l|l|} 
SA24 \\
\end{tabular} & 21 & 2790 & 95,8 & 62800 & 3,05 & \\
\hline & & SA25 & 21 & 2825 & 97,3 & 62800 & 3,09 & \\
\hline \multirow{5}{*}{ III } & \multirow{5}{*}{1,25} & SA31 & 21 & 2840 & 98,7 & 62800 & 3,14 & \multirow{5}{*}{3,12} \\
\hline & & SA32 & 21 & 2848 & 99,2 & 62800 & 3,16 & \\
\hline & & \begin{tabular}{|l|} 
SA33 \\
\end{tabular} & 21 & 2972 & 96,2 & 62800 & 3,06 & \\
\hline & & \begin{tabular}{|l|} 
SA34 \\
\end{tabular} & 21 & 2890 & 97,8 & 62800 & 3,11 & \\
\hline & & SA35 & 21 & 2865 & 98,8 & 62800 & 3,15 & \\
\hline
\end{tabular}

Pada pengujian kuat tarik terhadap 15 benda uji silinder dengan diameter $10 \mathrm{~cm}$ dan tinggi $20 \mathrm{~cm}$ diperoleh data seperti yang tertera pada tabel 3. Kuat tarik optimum diperlihatkan dari hasil kuat tarik pada katagori perbandingan aktivator Sodium Silikat terhadap Sodium Hidroksida adalah 1,25 dengan nilai kuat tarik sebesar 3,12 MPa. Data kuat tarik pada berbagai kategori aktivator disajikan dalam bentuk grafik sebagai berikut:

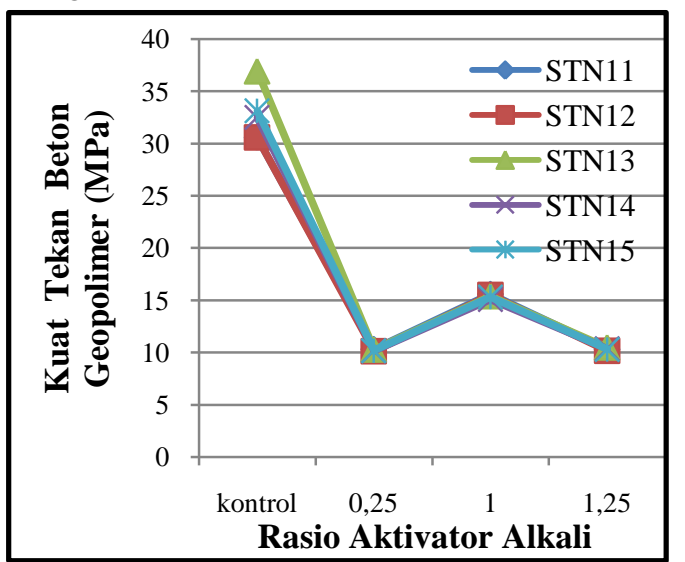

Gambar 3. Grafik Kuat Tekan Beton Geopolimer
Grafik pada Gambar 3 sumbu x memperlihatkan variasi rasio aktivator alkali sedangkan pada sumbu y memperlihatkan nilai kuat tekan yang diperoleh pada masingmasing rasio. Nilai kuat tekan tertinggi terlihat pada rasio aktivator alkali sama dengan satu dengan nilai kuat tekan rata-rata sebesar 15,34 MPa.

Adapun nilai kuat tarik dari beton geopolimer diperlihatkan pada Gambar 4. Grafik pada Gambar 4 memperlihatkan hasil pengujian terhadap kuat tarik terhadap beton geopolimer dengan menggunakan benda uji silinder diameter $10 \mathrm{~cm}$ dan tinggi $20 \mathrm{~cm}$.

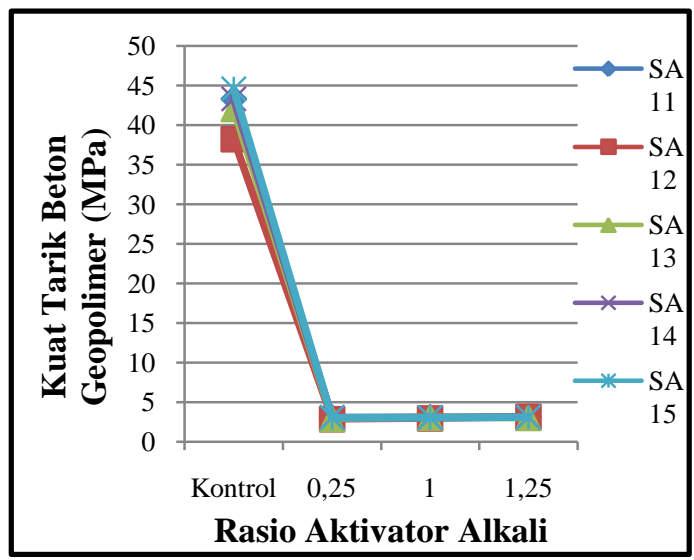

Gambar 4. Grafik Kuat Tarik Beton Geopolimer

Pada pengujian kuat tarik beton pengaruh variasi rasio aktivator alkali tidak tampak perbedaan yang signifikan antara rasio aktivator alkali 0,$25 ; 1,0$ dan 1,25 . Rata rata hasil kuat tarik diperoleh dibawah 3,12 MPa. Sebagaimana halnya kuat tarik pada beton normal, pada beton geopolimer kuat tarik berkisar sekitar $30 \%$ dari kuat tekan beton geopolimer.

\section{KESIMPULAN}

Berdasarkan hasil penelitian terhadap mekanikal propertis beton geopolimer dengan aktivator Sodium Silikat dan Sodium Hidroksida dapat disimpulkan sebagai berikut:

1. Persentase aktivator optimum diperoleh pada perbandingan Sodium Silikat 
terhadap Sodium Hidroksida adalah perbandingan berimbang yaitu 1:1 .

2. Kuat tekan beton geopolimer optimum pada umur 21 hari diperoleh sebesar 15,34 MPa.

3. Kuat tarik beton geopolimer optimum pada umur 21 hari adalah 3,12 MPa.

4. Kuat tekan mortar beton geopolimer pada umur 7 hari diperoleh sebesar 3,89 MPa.

5. Berdasarkan Gambar 3 Grafik Kuat Tekan Beton Geopolimer memperlihatkan pola karakteristik beton geopolimer pada masing-masing rasio aktivator terhadap kuat tekan. Kelima sampel pada kelas masing-masing rasio aktivator memperlihatkan hasil kuat tekan yang hampir sama atau dengan kata lain perlakuan antara satu benda uji dengan benda uji lainnya dapat dikatakan dapat dikatakan sama. Dengan demikian hasil yang diperoleh akurat.

6. Hal sama juga diperlihatkan pada pengujian tarik beton geopolimer, yaitu perbedaan nilai kuat tarik antara satu benda uji dengan benda uji lainya dapat dikatakan tidak signifikan. Dengan demikian hasil penelitian terhadap kuat tarik dapat dikatakan akurat.

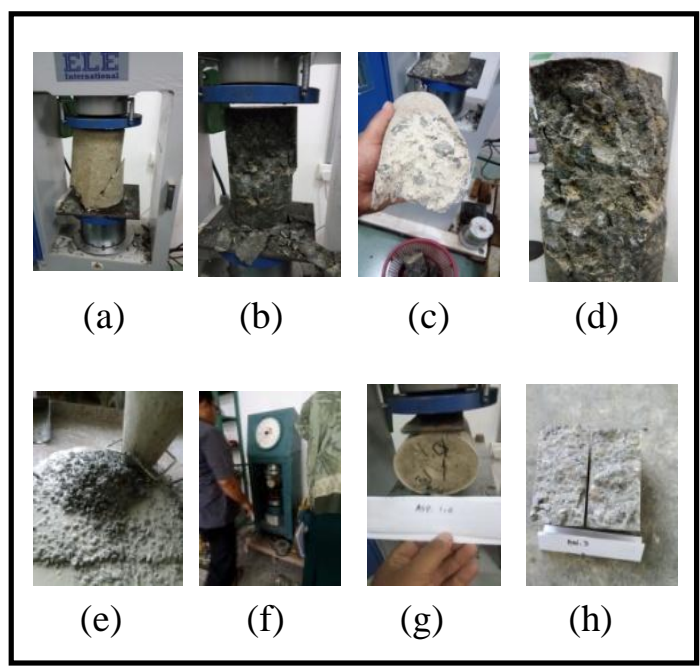

Keterangan:

(a) Pola retak pada pengujian kuat tekan beton geopolimer (b) Pola retak pada pengujian kuat tekan beton normal

(c) Potongan melintang beton geopolimer

(d) Potonangan melintang beton normal

(e) Tampilan campuran beton geopolimer

(f) Pengujian kuat tekan beton geopolimer

(g) Pengujian kuat tarik beton geopolimer

(h) Potongan melintang beton geopolimer

\section{DAFTAR PUSTAKA}

Bakri. 2008. Komponen Kimia dan Fisik Abu Sekam Padi sebagai SCM untuk Pembuatan Komposit Semen, Jurnal Perennial. 5(1):9-14.

Bui, et.al. 2005. Particle size Effect on the Strength of Rice Husk Ash Blended Gap-Grade Portland Cement Concrete, Cement and Concrete Composite. 27:357-366.

Chindraprasit, P, and Rukzon, S. 2007. Strength Porosity and Corrossion of Rsistance of Ternarry Blend Portland Cement, Rice Ash and Fly Ash Mortal, Construction and Building Material. 20:1601-1606.

C.Y Heah, etc. 2012. Study on Solid to Liquid and Alkaline Activator Ratios on Kaoline Based Geopolimer, Construction and Building Material Journal. 35(2012):912-922.

Daviddovits. 2008. Analize of Geopolymer Conctere Properties, Construction and Building Material. 20:1568-1576.

Ismail, M. S, and Waliuddin. A. M. 1996. Effect of Rice Husk on High Strength Concrete, Construction and Building Material. 10(11): 521-526.

Katsuki, H, Furuta, S, Watari ,T, and Kommens. 2005. ZSM -5- Zeolite porous carbon composite conventional and Microwave- Hydrothermal Synthetic from Carbonized Rice Husk Microporeous and Mesoporeous Material. 86:145-151.

Niken, S. 2010. Kajian terhadap Beton Polimer dengan Bahan Tambahan 
Abu Sekam Padi. Jurnal Teknik Sipil Institut Teknologi Bandung, Bandung.

Saraswati, V, and Song Ha-Wan. 2007. Corrossion Performance of Rice Husk Ash Blended Concrete, Construction and Building Material. 21: 1779-1784.

Singh, N.B, Rai, S, and Chaturreli, S. 2002. Hydration of Composite Cement,
Proggress in Christall Growth and Caracterization of Material. 171-179.

Yun Yong Kim, etc. 2014. Strength and Durability Performance of Alkali Activated Rice Husk Ash Geopolimer Mortar. Hindawi Publising Corpotaion Scientific World Journal. 305-315. 
ISSN 2086-9045 